\title{
Analysis of internal shading degree to a prototype of dynamics photovoltaic greenhouse through simulation software
}

\author{
Alvaro Marucci, Danilo Monarca, Massimo Cecchini, Andrea Colantoni, Andrea Cappuccini \\ Department of Agriculture, Forests, Nature and Energy, University of Tuscia, Viterbo, Italy
}

\begin{abstract}
In recent years the use of photovoltaic panels as cover materials for greenhouses developed a great interest due to the state's incentives obtainable by such applications. Shading caused by these elements inside the structure appears to be often too much for the normal development of agricultural activity. In this study it was analyzed the behaviour of shading caused by the photovoltaic panels inside a prototype of dynamic photovoltaic greenhouse whose particularity lies in the possibility of rotation of the panels along the longitudinal axis. The panels' rotation allows varying shading degree in function of some parameters such as latitude and the different solar angles. In order to avoid any reflection losses due to imperfect inclination of the photovoltaic panels, 24 highly reflective aluminium mirrors were prepared with the objective of recovering the portion of solar radiation otherwise lost by reflection. For the study it was used the simulation software Autodesk ${ }^{\circledR}$ Ecotect ${ }^{\circledR}$ Analysis which allows to analyse the path of the shadows during the day and throughout the year for any latitude considered. For this study it was analyzed shading with the panels in a horizontal position. It was also analyzed the evolution of the percentage of shading simulating different latitudes. The results obtained show a great variation of the shading degree inside the structure during a single day and during the year. We can conclude that integrating this analysis with the energy balance it is possible to study the behav-
\end{abstract}

Correspondence: Alvaro Marucci, Department of Agriculture, Forests, Nature and Energy (D.A.F.N.E.), University of Tuscia, via S. Camillo de Lellis, snc 01100, Viterbo, Italy.

Tel.: +39.0761.357365 - Fax: +39.0761 .357453 .

E-mail: marucci@unitus.it

Key words: Dynamic photovoltaic greenhouse; shading; agricultural production; energy production.

Contributions: Dynamic photovoltaic greenhouse was conceived and realized by Prof. A. Marucci and Dr. A. Cappuccini. The authors contributed to this work according to the areas of their expertise.

Received for publication: 16 June 2015

Accepted for publication: 12 November 2015 .

(C) Copyright A. Marucci et al., 2015

Licensee PAGEPress, Italy

Journal of Agricultural Engineering 2015; XLVI:483

doi:10.4081/jae.2015.483

This article is distributed under the terms of the Creative Commons Attribution Noncommercial License (by-nc 3.0) which permits any noncommercial use, distribution, and reproduction in any medium, provided the original author(s) and source are credited. iour of photovoltaic greenhouses in order to integrate the energy production from renewable energy sources and agricultural production.

\section{Introduction}

The greenhouses for crop production, widely diffused in the Mediterranean agricultural scenery, are structures that ensure continuity of the crops' production for the entire year regardless of external climatic variations. These structures exploit the greenhouse effect created inside them to reach and maintain the values of the different climatic parameters on the appropriate levels for the needs of plants. Environmental control in terms of light (Ioslovich, 2009), water (Katsoulas et al., 2006), air temperature (Sethi and Sharma, 2008), relative humidity (Kim et al., 2008), $\mathrm{CO}_{2}$ concentration (Korner et al., 2007) and ventilation (Bartzanas et al., 2004; Fatnassi et al., 2004) is regulated in greenhouses to improve yield and quality of crops (Yano et al., 2010).

These agricultural structures are used in the areas of central and northern Europe, where the open field cultivation of horticultural species, for much of the year, is difficult because of the unfavourable climate (Sonneveld et al., 2010a), and in the regions of southern Europe, where it is necessary to protect plants by drops in temperature (Stanghellini, 1987) that occur occasionally in the cold season (mostly at night).

During the coldest months in Mediterranean areas, the greenhouses face overheating problems during the day and excessive cold at night. Greenhouse heating is one of the most important and essential requirements for better growth during coldest period and especially during cold nights (Attar et al., 2013; Attar et al., 2014).

The agronomic research, the construction technology of the greenhouses and the selection of transparent cover materials are now oriented to try to reduce the use of energy artificial both to contain the production costs and to reduce the environmental impact (Campiglia et al., 2007; Marucci et al., 2011; Marucci and Pagniello, 2011).

In the Mediterranean areas the intensity of solar radiation reaching the Earth's surface at certain times of the year is often excessive in relation to the plants' needs so as to cause increment in internal air temperature to levels not tolerated by crops (Jolliet and Bailey, 1992; Medrano et al., 2005b) and by those who must operate (Marucci et al., 2012b; Marucci, 2013).

To ensure protection against thermal and energy excesses are used shading screens (Lorenzo et al., 2003; Medrano et al., 2005a) placed on the roofs of greenhouses, cooling systems of the type fog cooling (Katsoulas et al., 2009; Villarreal-Guerrero et al., 2012b; SánchezHermosilla et al., 2013) or, more simply, an increase in natural ventilation (Ganguly and Ghosh, 2009; Villarreal-Guerrero et al., 2012a, 2012b) through large openings or resorting to mechanical ventilation with electric fans (Bournet and Boulard, 2010; Coomans et al., 2013). All these solutions entail a considerable increase of the construction and operation costs. 
Systems for the control and management of air-conditioning and irrigation, as well as systems for handling of pallets and for the ventilation openings, use large amounts of electricity. Summing also that used in areas dedicated to post-harvest management, all the energy consumption of farms appears significant (Banaeian et al., 2011; Banos et al., 2011; Omid et al., 2011; Joudi and Farhan, 2015).

Consequently a sustainable plant production in the greenhouse should minimize the consumption of energy and compensate for the energy consumed with renewable energy (Bot et al., 2005; Yano et al., 2009; Yano et al., 2010). So the biggest problem in Mediterranean areas is to try to reduce significantly the solar radiation penetrating into the greenhouse in warm periods. This reduction can reach values also very high (more than $80 \%$ ) but it is conditioned by the needs of the cultivated plants that, for their biological activity, always need to well identified quantitative and qualitative levels of light (Hurd, 1983; Kittas and Bailie, 1998; Kittas et al., 1999; Lamnatou and Chemisana, 2013).

Solar radiation rejected by passive means of protection could be more conveniently used for other purposes having available appropriate means of collection and processing. Among these means particular interest are photovoltaic panels (PV) for converting a rate of solar energy into electricity.

In recent years, many researchers have studied the use of photovoltaic panels to provide electricity for the air conditioning of the greenhouse (AlIbrahim et al., 2006; Rocamora and Tripanagnostopoulos, 2006; AlShamiry et al., 2007; Campiotti et al., 2008; Sonneveld et al., 2008; Nayak and Tiwari, 2009; Yano et al., 2009; Ganguly et al., 2010; Sonneveld et al., 2010a, 2010b; Yano et al., 2010; Sonneveld et al., 2011; Lopez-Marin et al., 2012; Kadowaki et al., 2012). The results obtained are often favourable to the production of energy from photovoltaic elements but the shade created by them inside the structure appears to be excessive for a normal development of agriculture.

The search of other materials for the production of photovoltaic energy in substitution of silicon (Hailin et al., 2009; Shin et al., 2010; Marucci et al., 2012a; Marucci et al., 2013a, 2013b) and that are partially transparent to solar radiation shows the possibility of applying such PV materials on the roofs of the greenhouses, achieving the dual positive effect of reducing the radiation inside the greenhouse during periods of thermal excess and of using the surplus to produce electricity (Marucci et al., 2012a; Marucci et al., 2013b).

The goal of this research is to evaluate by simulation the possibility of using a prototype of dynamic photovoltaic greenhouse as a passive cooling system through the study of the variation of the shading degree inside the structure with PV panels in horizontal position.

\section{Materials and methods}

For the simulation it was used the prototype of dynamic photovoltaic greenhouse located at the experimental farm $N$. Lupori of the University of Tuscia in Viterbo (Lazio, Italy, $42^{\circ} 25^{\prime} 38^{\prime \prime} \mathrm{N}, 12^{\circ} 04^{\prime} 51^{\prime \prime}$ $\mathrm{E}, 306 \mathrm{~m}$ above sea level). The prototype was made of iron and glass with polycarbonate end caps and has an EW orientation with photovoltaic surface south facing. The orientation is a fundamental parameter for the production of photovoltaic energy and in the northern hemisphere the optimum is south (Hartner et al., 2015).

The shape of the cross section is asymmetrical in order to ensure a greater surface to the photovoltaic elements (no. 24) (Figure 1).

The dimensions of the prototype are:

- Length: $3.79 \mathrm{~m}$

- Width: $2.41 \mathrm{~m}$

- Ridge height: $2.05 \mathrm{~m}$
- Eaves height (south wall): $0.94 \mathrm{~m}$

- Eaves height (north wall): $1.36 \mathrm{~m}$

- Photovoltaic surface: $8.15 \mathrm{~m}^{2}$

- Photovoltaic pitch slope (south): $33^{\circ}$

- Not photovoltaic pitch slope (north): $51^{\circ}$

- Glass thickness: $3 \mathrm{~mm}$.

The prototype's particularity is the possibility of rotation of the photovoltaic panels along the longitudinal axis. The panels' rotation allows you to vary the degree of shading inside the structure due to the panels according to the weather conditions and the needs of the crop. You can then take into account the period of cultivation, the crop type and the parameters that influence the solar radiation: time of day, day of the year, latitude, altitude and degree of cloud cover. In order to avoid eventual reflection losses due to imperfect inclination of the photovoltaic panels, 24 highly reflective aluminium mirrors were provided with the objective of recovering the portion of solar radiation otherwise lost by reflection. The mirrors are always oriented according to the sun's trajectory in order to minimize the shading caused by them both inside the structure that on the photovoltaic panel.

A principle of the sustainable building design, which is based on the concept of geometry solar (Szokolay, 2007), provides that the dimensioning of any external arcades must be realized in such a way that during summer periods will prevent the entrance of solar rays inside the structure avoiding the increase in internal temperature and during the coldest periods instead will allow the entry of the rays so that it exploits the heat of the sun as partial heating.

On the basis of this principle it was thought to analyse the behaviour of internal shading to the prototype in the case wherein the panels were horizontal.

For this purpose it was used the simulation software Autodesk ${ }^{\circledR}$ Ecotect ${ }^{\circledR}$ Analysis. This software for sustainable architectural design is a complete analysis tool and can provide a wide range of capabilities for simulation and energy analysis aimed at improving the energy performance of existing buildings and new construction. It allows studying the positioning of the shadows of a given structure by displaying position and path of the sun for any date, time and latitude (Figure 2).

For this purpose, the variations in the internal shading degree were

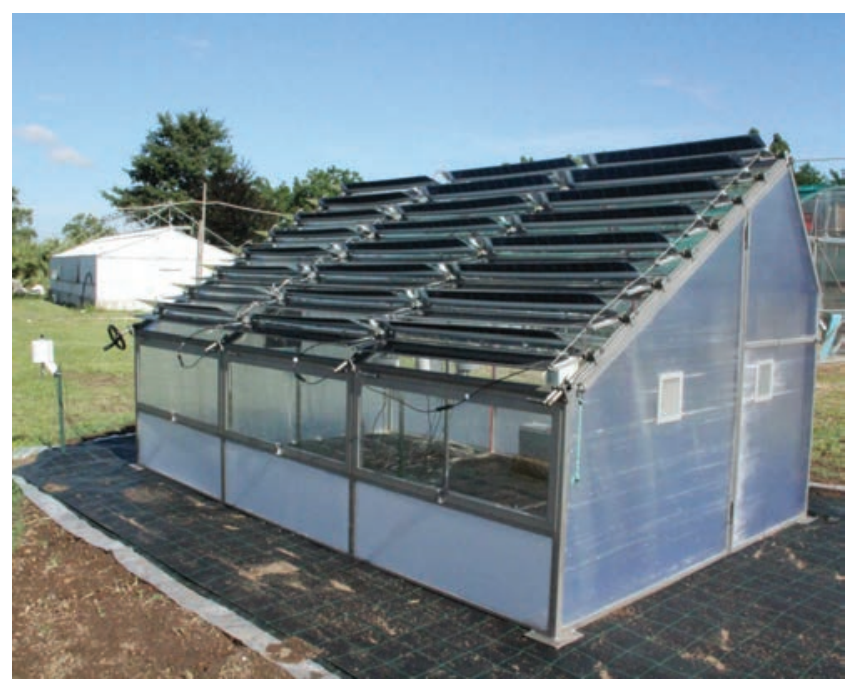

Figure 1. Prototype of dynamic photovoltaic greenhouse. 
examined during the fifteenth day of each month of the year at 12:00 when the angle of solar elevation is maximum in the day.

Subsequently it was simulated the variation of the shading degree during the year obtained with the panels in a horizontal position, as done previously, varying the latitude of the site. In this regard we simulated three different case studies that represent areas with latitude of about $42^{\circ} \mathrm{N}$ (Viterbo), $52^{\circ} \mathrm{N}$ and $62^{\circ} \mathrm{N}$.

\section{Results and discussion}

Figures 3 and 4 show simulations performed to analyse the variation of the shading's degree inside the prototype during the year by examining the fifteenth day of each month at 12:00 when during the day the sun elevation angle is at the peak. In order to do this it was taken into account only the part of light entering from the cover thus excluding the light part that penetrates from the sidewalls and from polycarbonate walls.

Figure 5 shows the shading percentages obtained from simulations comparing the area shaded by photovoltaic panels inside the structure with the total projection of the roof. By the results obtained and shown in Figure 5 it can be seen how the behaviour of shading follows the principle of sustainable building previously mentioned. During the coldest months (January, February, November and December) the shading percentage obtained with the panels in a horizontal position is lower or at least approaching 40\%, allowing a greater introduction of solar radiation and at the same time a rise in internal air temperature during periods of increased need for heat.

During the spring and autumn the shading percentage obtained was variable between $55 \%$ and $65 \%$.

During the summer, instead, shading obtained was always greater than $70 \%$ up to a maximum of $79 \%$ (June) allowing also a probable lowering of the internal air temperature.

From these results it is possible to envisage the use of this structure as a protection system able to improve the internal microclimate, not just with a significant energy saving, but also with the possibility of producing energy from renewable sources to power any electrical systems present.

Subsequently, was simulated the effect of panels' rotation on the shading degree, by rotating them at $10^{\circ}$ intervals. For this simulation were considered 12:00 of days related to the summer and winter solstices and the spring and autumn equinoxes.

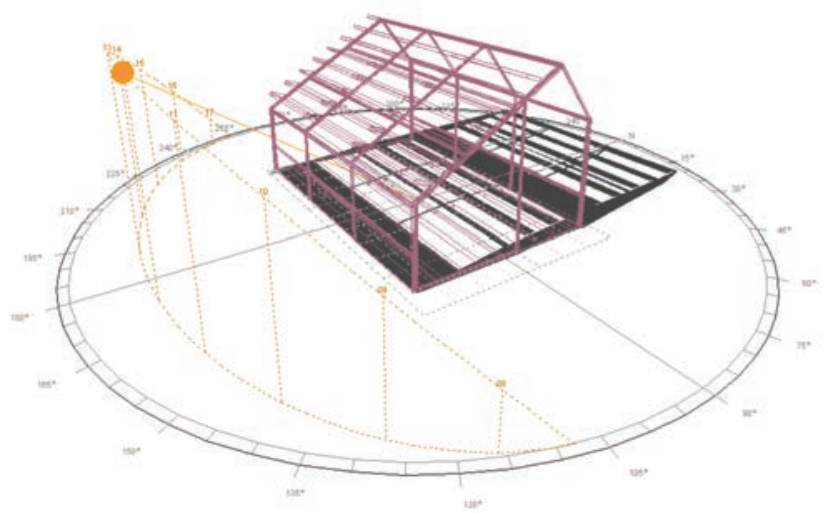

Figure 2. Example of the shadows analysis by means Autodesk® Ecotect ${ }^{\circledR}$ Analysis.
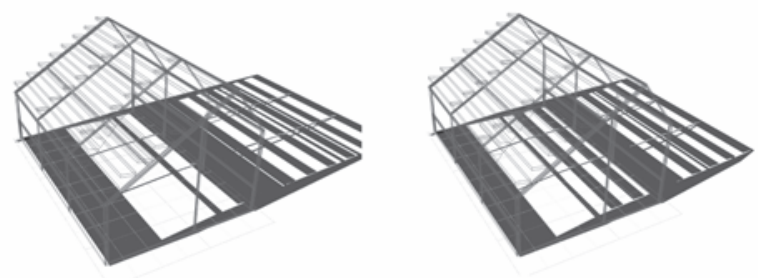

15 January 12:00

15 February 12:00
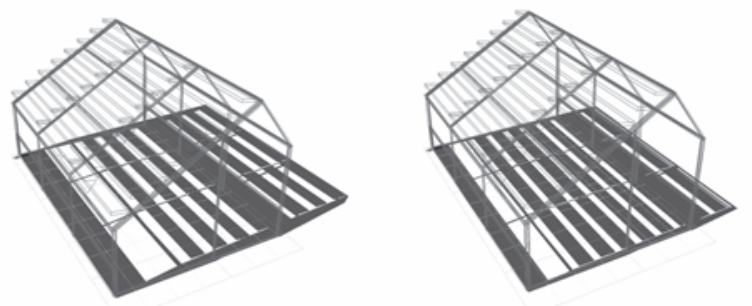

15 March 12:00

15 April 12:00

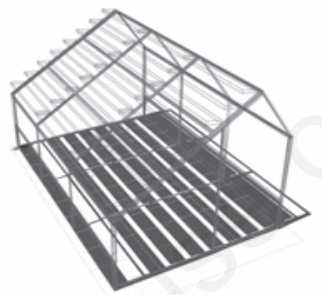

15 May 12:00

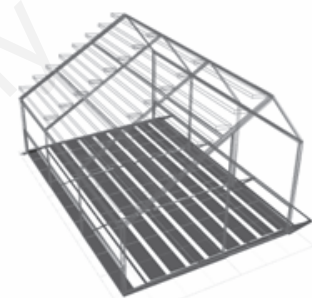

15 June 12:00

Figure 3. Elaborations by means Autodesk ${ }^{\circledR}$ Ecotect ${ }^{\circledR}$ Analysis of developments in the shadows during 6 months (January-June).
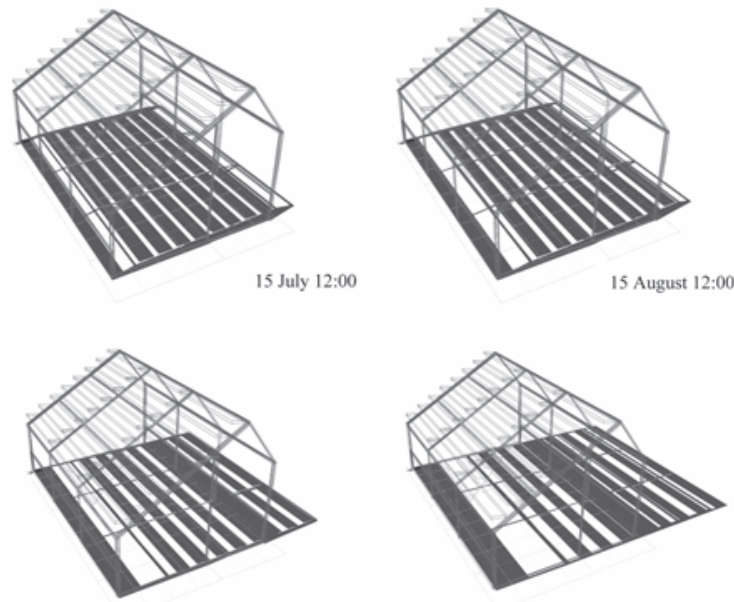

15 September 12:00

15 October 12:00
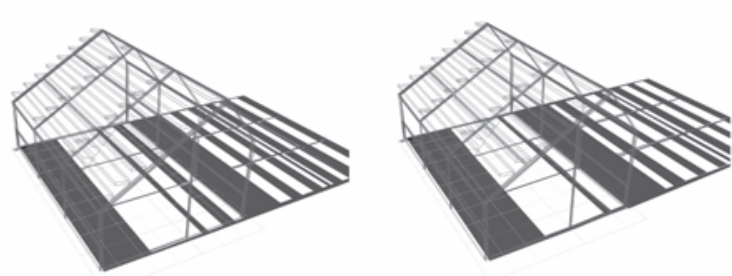

15 November 12:00

15 December 12:00

Figure 4. Elaborations by means Autodesk ${ }^{\circledR}$ Ecotect ${ }^{\circledR}$ Analysis of developments in the shadows during 6 months (July-December). 
During June, increasing the angle of inclination of the panels from a horizontal position $\left(30^{\circ}\right)$ in steps of $10^{\circ}$ was obtained a steady decrease in shading degree of about $8 \%$ for each $10^{\circ}$ of rotation. Conversely, by rotating the panel towards the flap, the shading percentage increases by $2 \%$ every $10^{\circ}$ of rotation. During the equinoxes increasing the angle of inclination of the photovoltaic panels at $10^{\circ}$ intervals, was obtained a decrease of the shading degree of $12 \%$. By decreasing the inclination, the shading percentage increases of $8-9 \%$ for every $10^{\circ}$ of variation. During the winter solstice increasing the angle of inclination of the panels at $10^{\circ}$ intervals was obtained a steady decrease in the shading percentage of about $16 \%$ for every $10^{\circ}$ of rotation. By turning the panel towards the flap, the shading percentage increases of $12 \%$ every $10^{\circ}$ of rotation.

In Table 1 are reported the hourly percentage values of the shading degree obtained with panels in horizontal position at $42^{\circ} \mathrm{N}$ latitude relative to the fifteenth day of each month of the year.

The variation in the degree of shading is rather significant considering different times of day along the same month, but even more so when one considers the monthly variations.

At this latitude, in the coldest months, the daily differences between

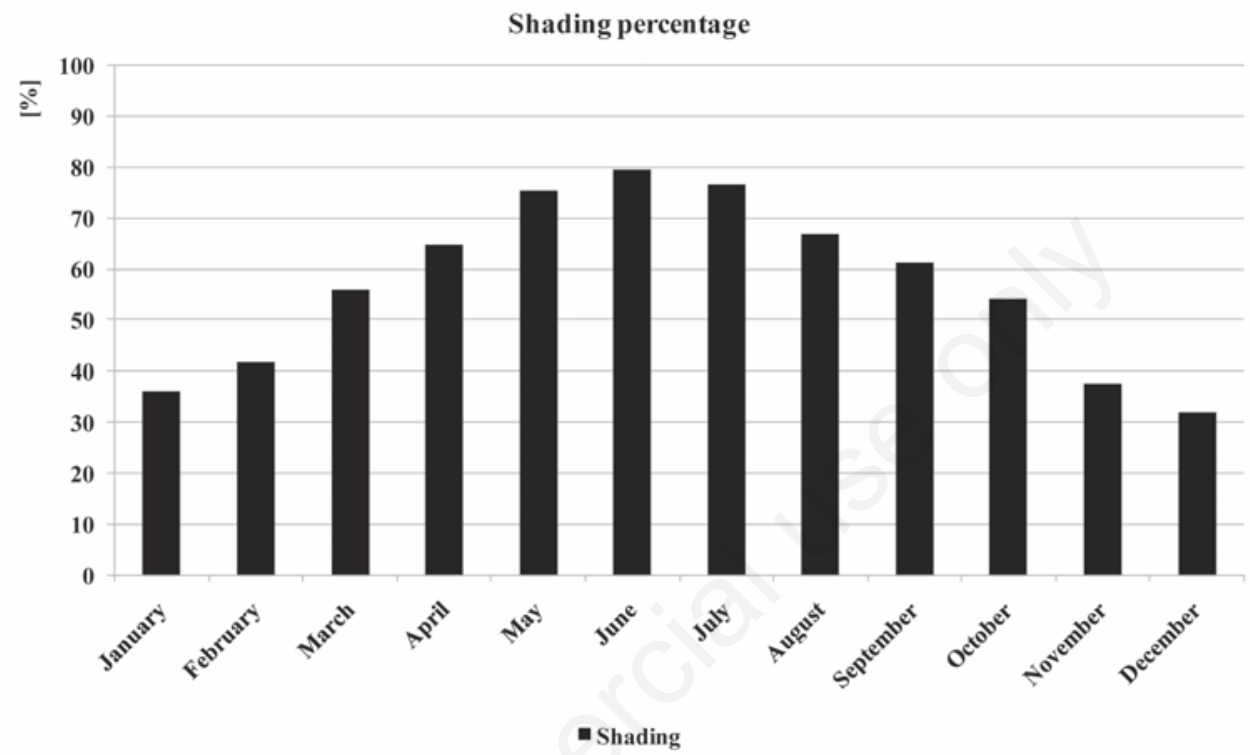

Figure 5. Shading percentages obtained from processing.

Table 1. Annual trend in the shading percentage at latitude $42^{\circ}$.

\begin{tabular}{|c|c|c|c|c|c|c|c|c|c|c|c|c|}
\hline & & & & & & & tude & & & & & \\
\hline h & JAN & FEB & MAR & APR & MAY & JUN & JUL & AUG & SEP & OCT & NOV & DEC \\
\hline 3 & & & & & & & & & & & & \\
\hline 4 & & & 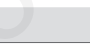 & & & & & & & & & \\
\hline 5 & & & & & 7 & 13 & 11 & & & & & \\
\hline 6 & & & & 15 & 25 & 30 & 28 & 20 & 4 & & & \\
\hline 7 & & 3 & 19 & 31 & 39 & 42 & 40 & 35 & 25 & 10 & & \\
\hline 8 & 12 & 23 & 34 & 43 & 49 & 51 & 50 & 46 & 38 & 27 & 15 & 8 \\
\hline 9 & 26 & 34 & 43 & 52 & 57 & 59 & 58 & 54 & 47 & 38 & 28 & 23 \\
\hline 10 & 34 & 42 & 50 & 58 & 64 & 66 & 65 & 61 & 54 & 45 & 36 & 32 \\
\hline 11 & 39 & 46 & 54 & 63 & 69 & 72 & 70 & 66 & 58 & 49 & 41 & 36 \\
\hline 12 & 40 & 48 & 56 & 64 & 71 & 74 & 73 & 67 & 59 & 51 & 42 & 38 \\
\hline 13 & 39 & 46 & 54 & 63 & 69 & 72 & 70 & 66 & 58 & 49 & 41 & 36 \\
\hline 14 & 34 & 42 & 50 & 58 & 64 & 66 & 65 & 61 & 54 & 45 & 36 & 32 \\
\hline 15 & 26 & 34 & 43 & 52 & 57 & 59 & 58 & 54 & 47 & 38 & 28 & 23 \\
\hline 16 & 12 & 23 & 34 & 43 & 49 & 51 & 50 & 46 & 38 & 27 & 15 & 8 \\
\hline 17 & & 3 & 19 & 31 & 39 & 42 & 40 & 35 & 25 & 10 & & \\
\hline 18 & & & & 15 & 25 & 30 & 28 & 20 & 4 & & & \\
\hline 19 & & & & & 7 & 13 & 11 & & & & & \\
\hline 20 & & & & & & & & & & & & \\
\hline 21 & & & & & & & & & & & & \\
\hline
\end{tabular}


minimum and maximum values vary between $28 \%$ and $45 \%$, while in spring and summer this difference results to be between $50 \%$ and $65 \%$.

Considering the shading degree achieved at 12:00 of each month, when the sun elevation angle is the greatest in the day, you can see the variation in this parameter. It varies from $38 \%$ achieved in the month of December to $74 \%$ in June.
Increasing the latitude of $10^{\circ}$ the trend remains the same but the difference between the maximum and minimum percentages along the same month is reduced (Table 2).

The shading hourly average percentage variations along each month are more or less extensive depending on the season under review. For example in autumn-winter the difference in shading percentage varies

Table 2. Annual trend in the percentage of shading at latitude $52^{\circ}$.

\begin{tabular}{|c|c|c|c|c|c|c|c|c|c|c|c|c|}
\hline & & & & & & $52^{\circ}$ lati & & & & & & \\
\hline h & JAN & FEB & MAR & APR & MAY & JUN & JUL & AUG & SEP & ОСТ & NOV & DEC \\
\hline 3 & & & & & & & & & & & & \\
\hline 4 & & & & & & 4 & & & & & & \\
\hline 5 & & & & & 13 & 20 & 17 & 5 & & & & \\
\hline 6 & & & & 16 & 28 & 32 & 31 & 22 & 4 & & & \\
\hline 7 & & & 16 & 31 & 39 & 42 & 41 & 35 & 23 & 4 & & \\
\hline 8 & & 16 & 30 & 41 & 48 & 50 & 49 & 44 & 35 & 21 & 5 & \\
\hline 9 & 16 & 28 & 39 & 49 & 55 & 57 & 56 & 52 & 43 & 32 & 20 & 13 \\
\hline 10 & 25 & 35 & 45 & 54 & 60 & 63 & 62 & 57 & 49 & 39 & 28 & 22 \\
\hline 11 & 30 & 39 & 48 & 58 & 64 & 67 & 66 & 61 & 52 & 43 & 32 & 27 \\
\hline 12 & 31 & 40 & 50 & 59 & 65 & 69 & 67 & 62 & 54 & 44 & 34 & 29 \\
\hline 13 & 30 & 39 & 48 & 58 & 64 & 67 & 66 & 61 & 52 & 43 & 32 & 27 \\
\hline 14 & 25 & 35 & 45 & 54 & 60 & 63 & 62 & 57 & 49 & 39 & 28 & 22 \\
\hline 15 & 16 & 28 & 39 & 49 & 55 & 57 & 56 & 52 & 43 & 32 & 20 & 13 \\
\hline 16 & & 16 & 30 & 41 & 48 & 50 & 49 & 44 & 35 & 21 & 5 & \\
\hline 17 & & & 16 & 31 & 39 & 42 & 41 & 35 & 23 & 4 & & \\
\hline 18 & & & & 16 & 28 & 32 & 31 & 22 & 4 & & & \\
\hline 19 & & & & & 13 & 20 & 17 & 5 & & & & \\
\hline 20 & & & & & & 4 & & & & & & \\
\hline 21 & & & & & $C$ & & & & & & & \\
\hline
\end{tabular}

Table 3. Annual trend in the percentage of shading at latitude $62^{\circ}$.

\begin{tabular}{|c|c|c|c|c|c|c|c|c|c|c|c|c|}
\hline & & & & & & $62^{\circ}$ & & & & & & \\
\hline h & JAN & FEB & MAR & APR & MAY & JUN & JUL & AUG & SEP & OCT & NOV & DEC \\
\hline 3 & & & & & & 6 & 2 & & & & & \\
\hline 4 & & & & & 9 & 17 & 14 & & & & & \\
\hline 5 & & & & 4 & 21 & 27 & 24 & 12 & & & & \\
\hline 6 & & & & 18 & 30 & 35 & 33 & 24 & 5 & & & \\
\hline 7 & & & 11 & 29 & 39 & 43 & 41 & 34 & 19 & & & \\
\hline 8 & & 4 & 23 & 37 & 45 & 49 & 47 & 41 & 29 & 11 & & \\
\hline 9 & & 16 & 31 & 43 & 51 & 54 & 53 & 47 & 36 & 22 & 4 & \\
\hline 10 & 8 & 23 & 36 & 48 & 55 & 58 & 57 & 51 & 41 & 28 & 13 & 4 \\
\hline 11 & 14 & 27 & 39 & 50 & 57 & 60 & 59 & 54 & 44 & 32 & 18 & 9 \\
\hline 12 & 15 & 28 & 40 & 51 & 58 & 61 & 60 & 55 & 45 & 33 & 19 & 11 \\
\hline 13 & 14 & 27 & 39 & 50 & 57 & 60 & 59 & 54 & 44 & 32 & 18 & 9 \\
\hline 14 & 8 & 23 & 36 & 48 & 55 & 58 & 57 & 51 & 41 & 28 & 13 & 4 \\
\hline 15 & & 16 & 31 & 43 & 51 & 54 & 53 & 47 & 36 & 22 & 4 & \\
\hline 16 & & 4 & 23 & 37 & 45 & 49 & 47 & 41 & 29 & 11 & & \\
\hline 17 & & & 11 & 29 & 39 & 43 & 41 & 34 & 19 & & & \\
\hline 18 & & & & 18 & 30 & 35 & 33 & 24 & 5 & & & \\
\hline 19 & & & & 4 & 21 & 27 & 24 & 12 & & & & \\
\hline 20 & & & & & 9 & 17 & 14 & & & & & \\
\hline 21 & & & & & & 6 & 2 & & & & & \\
\hline
\end{tabular}


between 15\% and 40\% while in spring-summer seasons this difference increases and it is between $40 \%$ and $65 \%$ with the maximum value obtained in June (65\%). At 12:00, the maximum shading degree was obtained in June (69\%) and the minimum in December (29\%).

In winter, at a latitude of $62^{\circ} \mathrm{N}$ (Table 3 ), the hourly average difference of the shading degree undergoes a sharp reduction (7-30\%) also due to the duration of the daylight during this period. Conversely, during summer season, when the days present even $20 \mathrm{~h}$ of light, the shading percentage variations varies between 40 and $60 \%$.

At 12:00 the maximum shading degree was obtained in June (61\%) and the minimum in December (11\%).

\section{Conclusions}

Through this analysis, it is possible to study the behaviour of photovoltaic greenhouses to any latitude and then to reconcile the agricultural activity and the production of energy from renewable sources in all seasons and in any place but taking into account that the optimum tilt angle of the photovoltaic panels is related to crop needs and energy production and varies depending to the latitude.

The horizontal position of the panels can be a great advantage especially in Mediterranean areas where, because of the high levels of solar radiation it is necessary to protect crops against energy and thermal excess. Conversely, in the regions with greater latitude where the problem of greenhouses is to perceive a greater quantity of solar radiation, the presence of photovoltaic panels turns out to be a great disadvantage because of their shading action.

By relating the optimum tilt angle for photovoltaic production with various solar angles and energy needs of the crops in production, it is possible to study the optimum position of the panels in order to reconcile the production of energy with agricultural production, bearing in mind that the main goal of these structures is the agricultural production. Further studies will be addressed by integrating this simulation with the energy balance of this structure in the presence of various crops more or less demanding in terms of light and energy and correlating the results obtained from the simulations with the values obtained from the prototype.

\section{References}

Al-Ibrahim A., Al-Abbadi N., Al-Helal I. 2006. PV greenhouse system e system description, performance and lesson learned. Acta Hortic. 710:251-64.

Al-Shamiry F.M.S., Ahmad D., Sharif A.R.M., Aris I., Janius R., Kamaruddin R. 2007. Design and development of a photovoltaic power system for tropical greenhouse cooling. Am. J. Appl. Sci. 4:386-9.

Attar I., Naili N., Khalifa N., Hazami M., Farhat A. 2013. Parametric and numerical study of a solar system for heating a greenhouse equipped with a buried exchanger. Energ. Convers. Manage. 70:163-73.

Attar I., Naili N., Khalifa N., Hazami M., Lazaar M., Farhat A. 2014. Experimental study of an air conditioning system to control a greenhouse microclimate. Energ. Convers. Manage. 79:543-53.

Banaeian N., Omid M., Ahmadi H. 2011. Energy and economic analysis of greenhouse strawberry production in Tehran province of Iran. Energ Convers Manage. 52:1020-25.

Banos R., Manzano-Agugliaro F., Montoya F., Gil C., Alcayde A., Gómez J. 2011. Optimization methods applied to renewable and sustain- able energy: a review. Renew. Sustain. Energy Rev. 15:1753-66.

Bartzanas T., Boulard T., Kittas C. 2004. Effect of vent arrangement on windward ventilation of a tunnel greenhouse. Biosyst. Eng. 88:479-90.

Bot G., van de Braak N., Challa H., Hemming S., Rieswijk T.H., van Straten G., Verlodt I. 2005. The solar greenhouse: state of the art in energy saving and sustainable energy supply. Acta Hortic. 691:501-8.

Bournet P.E., Boulard T. 2010. Effect of ventilator configuration on the distributed climate of greenhouses: a review of experimental and CFD studies. Comput. Electron. Agr. 74:195-217.

Campiglia E., Colla G., Mancinelli R., Rouphael Y., Marucci A. 2007. Energy balance of intensive vegetable cropping systems in central Italy. Acta Hortic. 747:185-91.

Campiotti C., Dondi F., Genovese A., Alonzo G., Catanese V., Incrocci L., Bibbiani C. 2008. Photovoltaic as sustainable energy for greenhouse and closed plant production system. Acta Hortic. 797:373-8.

Coomans M., Allaerts K., Wittemans L., Pinxteren D. 2013. Monitoring and energetic performance of two similar semi-closed greenhouse ventilation systems. Energ. Convers. Manage. 76:128-36.

Fatnassi H., Boulard T., Lagier J. 2004. Simple indirect estimation of ventilation and crop transpiration rates in a greenhouse. Biosyst. Eng. 88:467-78.

Ganguly A., Ghosh S. 2009. Model development and experimental validation of a floriculture greenhouse under natural ventilation. Energ. Buildings. 41:521-7.

Ganguly A., Misra D., Ghosh S. 2010. Modeling and analysis of solar photovoltaic-electrolyzer-fuel cell hybrid power system integrated with a floriculture greenhouse. Energ. Buildings. 42:2036-43.

Hailin H., Sheng-Chin K., Li-Mei Y., Nicho M.E., Penner R. 2009. Photovoltaic devices based on electrochemical-chemical deposited CdS and poly3-octylthiophene thin films. Sol. Energ. Mat. Sol. C. 93:51-4.

Hartner M., Ortner A., Hiesl A., Haas R. 2015. East to west - The optimal tilt angle and orientation of photovoltaic panels from an electricity system perspective. Appl. Energy. 160:94-107.

Hurd R.G. 1983. Energy saving techniques in greenhouses and their effects on the tomato crops. Sci. Hortic. Amsterdam. 33: 94-101.

Ioslovich I. 2009. Optimal control strategy for greenhouse lettuce: incorporating supplemental lighting. Biosyst. Eng. 103:57-67.

Jolliet O., Bailey B.J. 1992. The effect of climate on tomato transpiration in greenhouse: measurements and models comparison. Agric. For. Meteorol. 58:43-63.

Joudi K.A., Farhan A.A. 2015. A dynamic model and an experimental study for the internal air and soil temperatures in an innovative greenhouse. Energ. Convers. Manage. 91:76-82.

Kadowaki M., Yano A., Ishizu F., Tanaka T., Noda S. 2012. Effects of greenhouse photovoltaic array shading on Welsh onion growth. Biosyst. Eng. 111:290-7.

Katsoulas N., Kittas C., Dimokas G., Lykas C.H. 2006. Effect of irrigation frequency on rose flower production and quality. Biosyst. Eng. 93:237-44.

Katsoulas N., Savvas D., Tsirogiannis I., Merkouris 0., Kittas C. 2009. Response of an eggplant crop grown under Mediterranean summer conditions to greenhouse fog cooling. Sci. Hortic. Amsterdam. 123:90-8.

Kim K., Yoon J.Y., Kwon H.J., Han J.H., Son J.E., Nam S.W., Giacomelli G.A., Lee I.B. 2008. 3-D CFD analysis of relative humidity distribution in greenhouse with a fog cooling system and refrigerative dehumidifiers. Biosyst. Eng. 100:245-55.

Kittas C., Bailie A. 1998. Determination of the spectral properties of several greenhouse cover materials and evaluation of specific parameters related to plant response. J. Agr. Eng. Res. 71:193-202.

Kittas C., Baille A., Giaglaras P. 1999. Influence of covering material and shading on the spectral distribution of light in greenhouses. J. Agr. 
Eng. Res. 73:341-51.

Korner 0., Van’t Ooster A., Hulsbos M. 2007. Design and performance of a measuring system for C02 exchange of a greenhouse crop at different light levels. Biosyst. Eng. 97:219-28.

Lamnatou C., Chemisana D. 2013. Solar radiation manipulations and their role in greenhouse claddings: Fluorescent solar concentrators, photoselective and other material. Renew. Sust. Energ. Rev. 27:175-90.

Lopez-Marin J., Galvez A., Gonzalez A., Egea-Gilabert C., Fernandez J.A. 2012. Effect of shade on yield, quality and photosynthesis-related parameters of sweet pepper plants. Acta Hortic. 956:545-52.

Lorenzo P., Sánchez-Guerrero M.C., Medrano E., García M.L., Caparrós I., Giménez M. 2003. External greenhouse mobile shading: effect on microclimate, water use efficiency and yield of a tomato crop grown under different salinity levels of the nutrient solution. Acta Hort. 609:181-6.

Marucci A. 2013. Workers' health and safety in Mediterranean greenhouses. J. Food. Agric. Environ. 11:35-9.

Marucci A., Campiglia E., Colla G., Pagniello B. 2011. Environmental impact of fertilization and pesticide application in vegetable cropping systems under greenhouse and open field conditions. J. Food. Agric. Environ. 9:840-46.

Marucci A., Gusman A., Pagniello B., Cappuccini A. 2013b. Limits and prospects of photovoltaic covers in Mediterranean greenhouse. J. Agric. Eng. 44:1-8.

Marucci A., Monarca D., Cecchini M., Colantoni A., Allegrini E., Cappuccini A. 2013a. Use of Semi-transparent photovoltaic films as shadowing systems in Mediterranean greenhouses. ICCSA 2013, Part II, LNCS. 7972:231-41.

Marucci A., Monarca D., Cecchini M., Colantoni A., Manzo A., Cappuccini A. 2012a. The semitransparent photovoltaic films for Mediterranean greenhouse: a new sustainable technology. Math. Prob. Eng. 2012:451934.

Marucci A., Pagniello B. 2011. Simulation of the growth and the production of the tomato in typical greenhouses of the Mediterranean environment. J. Food. Agric. Environ. 9:407-11.

Marucci A., Pagniello B., Monarca D., Cecchini M., Colantoni A., Biondi P. 2012b. Heat stress suffered by workers employed in vegetable grafting in greenhouses. J. Food. Agric. Environ. 10:1117-21.

Medrano E., Lorenzo P., Sánchez-Guerrero M.C., García M.L., Caparrós I., Coelho G., Giménez M. 2005a. Water and nutrient use efficiency of a tomato crop as affected by two refrigeration methods: external mobile shading and fog system. Acta Hort. 697:463-7.

Medrano E., Lorenzo P., Sánchez-Guerrero M.C., Montero J.I. 2005b. Evaluation and modelling of greenhouse cucumber-crop transpiration under high and low radiation conditions. Sci. HorticAmsterdam. 105:163-75.

Nayak S., Tiwari G.N. 2009. Theoretical performance assessment of an integrated photovoltaic and earth air heat exchanger greenhouse using energy and exergy analysis methods. Energ. Buildings. 41:888-96.
Omid M., Ghojabeige F., Delshad M., Ahmadi H. 2011. Energy use pattern and benchmarking of selected greenhouses in Iran using data envelopment analysis. Energ. Convers. Manage. 52:153-62.

Rocamora M.C., Tripanagnostopoulos Y. 2006. Aspects of PV/T solar system application for ventilation needs in greenhouses. Acta Hortic. 719:239-46

Sánchez-Hermosilla J., Páez F., Rincón V.J., Callejón A.J. 2013. Evaluation of a fog cooling system for applying plant-protection products in a greenhouse tomato crop. Crop. Prot. 48:76-81.

Sethi VP, Sharma SK. 2008. Survey and evaluation of heating technologies for worldwide agricultural greenhouse applications. Sol. Energy. 82:832-59.

Shin G.H., Allen C.G., Potter B.G. Jr. 2010. RF-sputtered Ge-ITO nanocomposite thin films for photovoltaic applications. Sol. Energ. Mat. Sol. C. 94:797-802.

Sonneveld P.J., Holterman H.J., Swinkels G.L.A.M., van Tuijl B.A.J., Bot G.P.A. 2008. Solar energy delivering greenhouse with an integrated NIR filter. Acta Hortic. 801:703-10.

Sonneveld P.J., Swinkels G.L.A.M., Bot G.P.A., Flamand G. 2010a. Feasibility study for combining cooling and high grade energy production in a solar greenhouse. Biosyst. Eng. 105:51-8.

Sonneveld P.J., Swinkels G.L.A.M., Campen J., van Tuijl B.A.J., Janssen H.J.J., Bot G.P.A. 2010b. Performance results of a solar greenhouse combining electrical and thermal energy production. Biosyst. Eng. 106:48-57.

Sonneveld P.J., Swinkels G.L.A.M., van Tuijl B.A.J., Janssen H.J.J., Campen J., Bot G.P.A. 2011. Performance of a concentrated photovoltaic energy system with static linear Fresnel lenses. Sol. Energy. 85:432-42.

Stanghellini C. 1987. Transpiration of greenhouse crops. PhD thesis, Wageningen University, 150 pp.

Szokolay S.V. 2007. Solar geometry. Passive and Low Energy Architecture International in association with Department of Architecture, The University of Queensland, Brisbane, $45 \mathrm{pp}$.

Villarreal-Guerrero F., Kacira M., Fitz-Rodríguez E., Linker R., Kubota C., Giacomelli G.A., Arbel A. 2012a. Comparison of three evapotranspiration models for a greenhouse cooling strategy with natural ventilation and variable high pressure fogging. Sci. Hortic. Amsterdam. 134:210-21.

Villarreal-Guerrero F., Kacira M., Fitz-Rodríguez E., Linker R., Kubota C., Giacomelli G.A., Arbel A. 2012b. Simulated performance of a greenhouse cooling control strategy with natural ventilation and fog cooling. Biosyst. Eng. 111:217-28.

Yano A., Furue A., Kadowaki M., Tanaka T., Hiraki E., Miyamoto M., Ishizu F., Noda S. 2009. Electrical energy generated by photovoltaic modules mounted inside the roof of a north-south oriented greenhouse. Biosyst. Eng. 103:228-38.

Yano A., Kadowaki M., Furue A., Tamaki N., Tanaka T., Hiraki E. 2010. Shading and electrical features of a photovoltaic array mounted inside the roof of an east-west oriented greenhouse. Biosyst. Eng. 106:367-77. 